\title{
ВТОРИЧНЫЕ ИЗМЕНЕНИЯ НИКЕЛЕНОСНЫХ ПОРОД ДУКУКСКОГО КОМПЛЕКСА КАМЧАТКИ
}

\author{
Д. В. Еременко, А. В. Еременко, Г. С. Золотарева \\ Воронежский государственный университет \\ Поступила в редакцию 17 февраля 2019 г.
}

\begin{abstract}
Аннотация: в статье приведены результаты изучения никеленосных пород дукукского комплекса южной (Квинум-Кувалорогской) группы Камчатской никеленосной провинции, характеризующихся специифическими условиями образования. На их формирование существенно влияла субдукционная компонента, которая обеспечивала повышенную флюидонасыщенность исходных расплавов, а также условия сжатия, благодаря которым отликвировавшаяся сульфидная часть теряет связь с ближайшими окружающими ее материнскими породами вплоть до образования самостоятельных тел - интрузий (Шануч) [1, 2]. В этой связи, важным фактором представляется проявление постмагматических преобразований пород. Вторичные изменения минерального вещества изученных пород указывают на существенный вклад в рудный прочесс эпигенетических изменений, что согласуется с представлениями о более высокой гидратированности исходных расплавов. Графические срастания карбоната с пирротином, многочисленные единичные волокна серпентина в рудной массе и ряд других признаков позволяют сделать вывод о том, что вторичные изменения имели место до окончательной кристаллизации массивов в позднемагматическую стадию.
\end{abstract}

Ключевые слова: дукукский комплекс, серпентинизаиия, сидеронитовая структура, графические срастания, тальк-хлоритовые породы, Камчатка, Хихку, Квинум, Тундровый.

\section{SECONDARY CHANGES OF NICKEL-BEARING ROCKS OF THE DUKUKSKY COMPLEX OF KAMCHATKA}

\begin{abstract}
: the article presents the results of the research of the rocks of the dukuksky complex in southern (Kvinum-Kuvalorog) group of the Kamchatka nickel-bearing province, which characterized by specific formation conditions. Their formation was significantly influenced by subduction component, which provided enhanced fluid saturation of initial melts, as well as compression conditions, due to which the segregation sulphide part loses contact with the surrounding parent rocks until the formation of independent bodies - intrusions (Shanuch) [1, 2]. In this regard, an important factor is the represents of existents post-magmatic transformations of rocks. Secondary changes in the mineral matter are emphasized indicate a significant contribution to the ore process of epigenetic changes, which is consistent with the ideas of higher hydration of the initial melts. The graphical intergrowths of carbonate and pyrrhotite, numerous single serpentine fibers within the ore mass, and a number of other signs suggest that most of the secondary changes took place before the final crystallization of the massifs in the late magmatic stage.

Key words: dukuksky complex, serpentinization, sideronite structure, graphical convergence, talcchlorite rocks.
\end{abstract}

\section{Введение}

Месторождение Шануч является уникальным по содержаниям никеля в руде (Ni до 13\%) [2]. На данный момент значительная часть месторождения уже отработана, а поиски новых продуктивных тел до сих пор не увенчались успехом, несмотря на значительные объёмы поисковых работ. Отсутствие положительных результатов поисковых работ вызвано неприменимостью концепции поисков классических ультрамафит-мафитовых расслоенных комплексов в условиях Камчатского региона. Наиболее актуальным в данном случае является пересмотр ликвационной природы происхождения богатых медно-никелевых руд и внесение в эти представления существенных корректив с точки зрения эпигенетического процесса для изменения идеологии поисков и разведки $\mathrm{Cu}-\mathrm{Ni}$ руд шанучского типа.

Медно-никелевое оруденение Шануча характеризуется спецификой, существенно отличающейся от типичного ликвационного оруденения, характерного 
для Норильского типа месторождений. Ликвационное оруденение Норильского типа контролируется внутриплитной обстановкой, что предполагает относительно «сухой» состав магматических расплавов. Медно-никелевое оруденение Шанучского типа формировалось в условиях, контролируемых субдукционной компонентой $[2,3]$, что определяет повышенную гидратированность первичных никеленосных расплавов. В этой связи, важным фактором представляется проявление постмагматических преобразований. Строго говоря, для ликвационного типа разделение на магматические и постмагматические фазы является весьма условным, так как для силикатного расплава температура кристаллизации существенно выше (более $1000^{\circ} \mathrm{C}$ ), чем для сульфидного (350$\left.400^{\circ} \mathrm{C}\right)$. Из этого следует, что после кристаллизации силикатного расплава, сульфидный расплав ещё находится в ликвидусной фазе. Указанные факторы (повышенная гидратированность исходного расплава и существенные различия в температурах кристаллизации для силикатного и сульфидного расплавов) обусловливают сложное сочетание структурнотекстурных особенностей руд (от массивных и вкрапленных до прожилковых и прожилково-вкрапленных) и, как следствие, своеобразие постмагматических преобразований.

Целью предлагаемой статьи является выявление особенностей упомянутых преобразований на заключительной стадии рудно-магматического процесса. В основе исследований лежит изучение минерального состава главных типов медно-никелевого оруденения, связанного с массивами дукукского комплекса, относящихся к южной (Квинум-Кувалорогской) группе Камчатской никеленосной провинции (южное обрамление Срединно-Кристаллического массива Камчатки (CKM)).

\section{Геологическая ситуация}

Дукукский комплекс (позднемеловой возраст) объединяет ряд интрузий в форме штоков, лополитов, субпластовых тел базит-гипербазитового состава (кортландитовый тип), обычно с простым внутренним строением и линейными размерами выходов в диапазоне $1500 \times 900$ м, $700 \times 400$ м. Интрузии приурочены к зоне влияния Квинум-Степановского разлома. Контакты интрузивных тел с вмещающими породами ровные, как правило, сопровождаются кварцевыми прожилками и ороговикованием вмещающих пород с многочисленными их ксенолитами в зоне эндоконтактов [2].

В интрузивных телах Тундровый I и Тундровый II, расположенных в юго-западной части участка Тундровый (рис. 1), верхние части штоков представлены меланократовыми габброидами, сильно измененными и преобразованными в слюдисто-тремолитовые, тальк-хлоритовые породы. В центральных частях тел сохранились останцы первичных кортландитов, минеральный состав которых представлен роговой обманкой (паргаситом), оливином, клинопироксеном (авгитом), шпинелью, магнетитом, пентландитом. Часто краевые нижние части массивов сложены преимущественно горнблендитами. Сульфидное оруденение контролируется меланократовыми габброидами в нижних частях интрузий. Рудопроявления Квинум I и Квинум II представляют собой штокообразные за счет тектонизации, линзовидные тела, характеризующиеся пологими контактами с вмещающими породами. Сложены диоритами и габброидами, преобразованными в тальк-хлоритовые и слюдисто-тремолитовые породы. На участке Хихку расположено штокообразное интрузивное тело, сложенное диоритами и кварцевыми диоритами [2]. В северо-западной части тела преобладают диориты, более меланократовые близ северо-западного фланга, к центру тела в породах возрастает содержание биотита до $10 \%$. Юговосточная часть интрузии сложена гранатсодержащими (до 15-20\% граната) кварцевыми диоритами. На южных склонах г. Хихку наблюдаются тела-развалы апопироксенитовых серпентинитов.

Все перечисленные массивы являются дериватами дифференцированного очага, находящегося на промежуточных глубинах $[1,2]$, что типично для периконтинентальных покровно-складчатых областей, формирующихся в условиях сжатия, в противовес массивам внутриплитных обстановок, где дифференцированные массивы остаются в первоначальном виде, слаботектонизированы, в меньшей степени подвержены вторичным изменениям (например, Норильск-1, Талнах, Октябрьское), а отликвированная часть рудного вещества приурочена к наиболее основным дериватам расслоенных комплексов.

\section{Методы аналитических исследований}

Образцы пород и руд отобраны из мафитультрамафитовых никеленосных интрузий дукукского комплекса в пределах поисковых участков Тундровый, Квинум и Хихку и проведено их петрографическое изучение. Составы рудных минералов изучались на растровом электронном микроскопе Jeol JSM-6380 LV с энергодисперсионным спектрометром INCA 250. По результатам аналитических исследований для зерен 60 рудных минералов из интрузивных тел дукукского комплекса Тундровый I, II, Квинум I, II и рудного тела участка Хихку определены средневзвешенные содержания компонентов, рассчитана их химическая формула, попутно стехиометрическим путем вычислено отношение объемов автометасоматических минералов, образовавшихся в ходе становления массивов.

\section{Петрография и минералогия}

Петрографическое изучение пород, слагающих вышеперечисленные интрузивные тела, позволило выявить некоторые особенности никеленосного магматизма южной Камчатки. Эти особенности наиболее отчетливо проявлены в рудных серпентинитах, талькхлоритовых породах и габбро-диоритах, содержащих богатое сульфидное оруденение. 


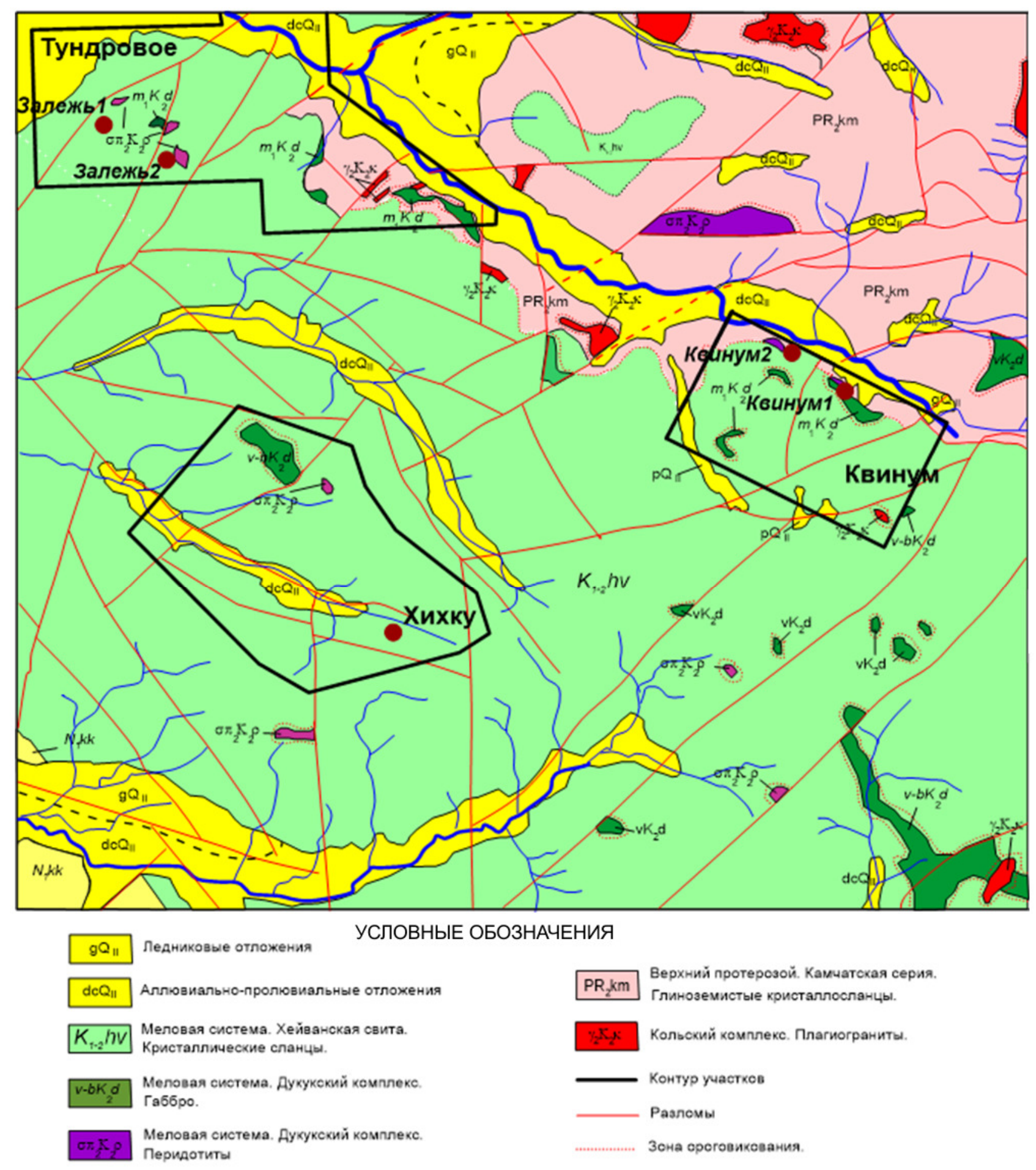

Puc. 1. Схематическая карта рудных объектов участков Квинум, Тундровый и Хихку Квинум-Тундрового рудного поля [10] (Масштаб 1:100 000).

\section{Серпентинитьл}

Рудные серпентиниты развиты на участке Хихку и представляют собой среднезернистые породы, характеризующиеся двумя реликтовыми структурами: сидеронитовой (в рудной массе присутствуют идиоморфные зерна серпентинизированных оливина и пироксена), переходящей участками в пойкилитовую (крупные зерна роговой обманки, замещенные хлори- том, с угловатыми пойкилитовыми включениями серпентинизированных оливина и пироксена).

Минеральный состав серпентинитов следующий (в \% от объема породы): серпентин - 30-35, карбонат 5-10, хлорит - 5, тальк - 5, рудные минералы - 45-50.

Серпентин образует полные псевдоморфозы по оливину, пироксену, представлен тонковолокнистой разновидностью - хризотилом, развивающимся по 
периферии зерна, и микрозернистой пластинчатой разновидностью антигоритом, выполняющим внутренние части зерен.

Карбонат пространственно связан с серпентинизированными зернами и образует ксеноморфные графические срастания с рудным веществом, что можно наблюдать в серпентините с сидеронитовой структурой (рис. 2А).

В рудной массе серпентинитов наблюдается боль- шое количество разорванных серпентинизированных зерен, разобщенных волокон хризотила, листочков талька, многие из которых изогнуты. При разрыве серпентинизированных зерен вдоль волокон границы трещин гладкие, поперек - щетковидные (рис. 2Б). Все трещинки заполнены рудными минералами, что говорит о деформации серпентинизированных зерен и окончательной кристаллизации рудного вещества после этой деформации.

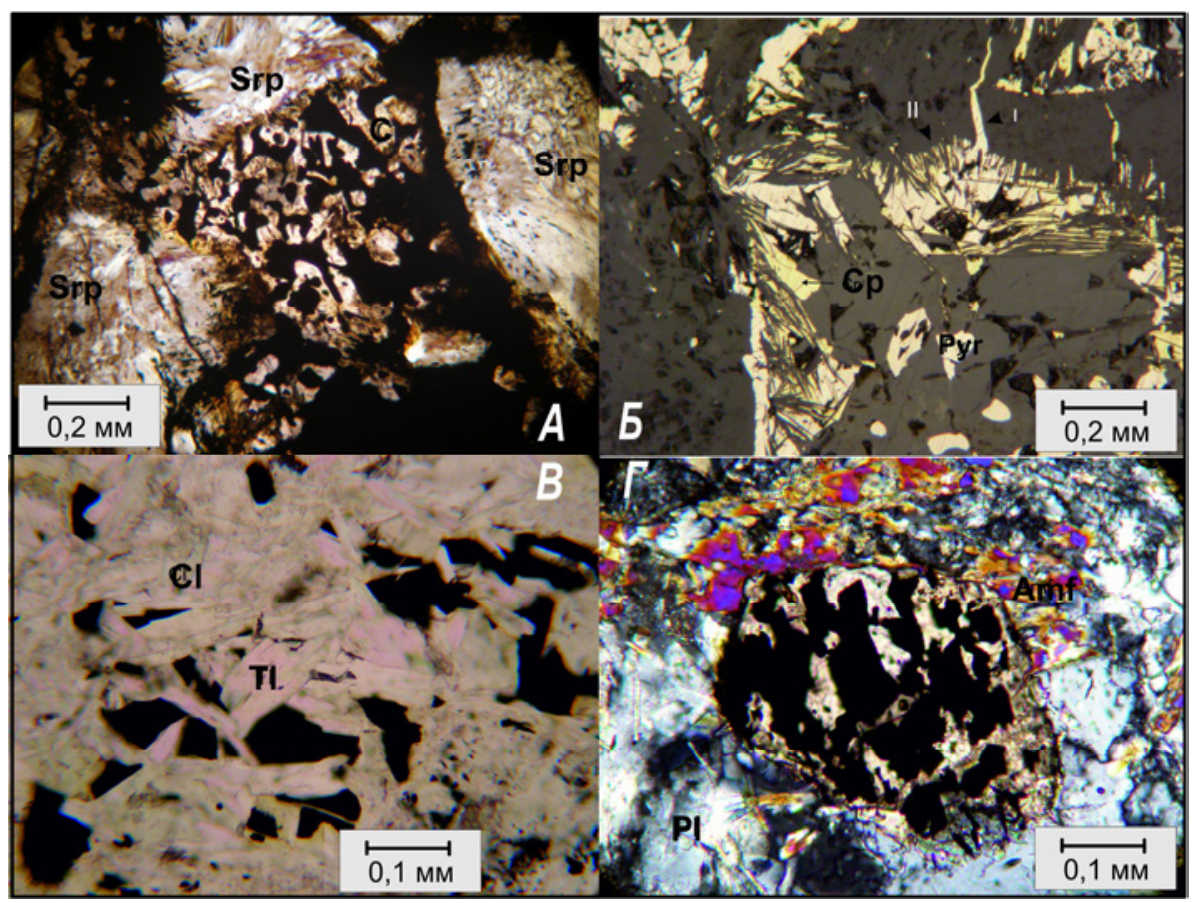

Puс. 2. Текстурно-структурные особенности рудных минералов. $A$ - взаимное прорастание карбоната и рудного минерала (черное). $C$ - карбонат, $S r p$ - серпентин. Николи параллельны. $\quad$ - медно-никелевая руда ( $I$ - трещина ориентированная вдоль волокон серпентина, заполненная рудным минералом, $I I$ - разобщенные волокна серпентина в рудной массе). Аншлиф. $C p-$ халькопирит, $P y r$ - пирротин. $B$ - угловатые выделения рудного минерала (черное) в межзерновом пространстве тальк-хлоритовой породы. Шлиф, николи параллельны. $C l$ - хлорит, $T l$ - тальк. $\Gamma$ - фрагмент зерна темноцветного минерала, замещенный рудным минералом (черное) и карбонатом, которые образуют графическое срастание. Николи скрещены.

К границе серпентинизированных зерен приурочены выделения талька с реликтовой спайностью роговой обманки (трещинки выполнены мелкодисперсными включениями магнетита). Такая же реликтовая спайность наблюдается в хлорите (на участках с пойкилитовой структурой). Наблюдаются замещения хлорита тальком с наследованием спайности роговой обманки и выделением магнетита. Прослеживается следующая последовательность вторичных изменений: 1) оливин и пироксен $\rightarrow$ серпентин + карбонат; 2) роговая обманка $\rightarrow$ хлорит + магнетит $\rightarrow$ тальк + магнетит.

Минеральный состав медно-никелевых руд серпентинитов следующий (в \% от объема вкраплений сульфидов): пирротин - 25-30, пентландит - 20-25, халькопирит $-20-25$, магнетит -10 , валлериит $-2-3$ (продукт замещения пирротина и пентландита), встречаются единичные зерна пирита. По характеру распределения рудных минералов серпентиниты можно отнести к равномерновкрапленным рудам. Рудные минералы кремово-желтого цвета, распреде- лены в породе равномерно, занимают пространство между идиоморфными зернами силикатных минералов, характеризуются аллотриоморфнозернистой структурой (выделения пирротина, халькопирита и магнетита ксеноморфны), с элементами порфировидной (пентландит образует идиоморфные изометричные зерна). Порфировидные выделения пентландита на фоне общей ксеноморфной массы говорят о более раннем его выделении [4]. Таким образом, последовательность выделения рудных минералов представляется следующей: пентландит $\rightarrow$ пирротин + халькопирит + магнетит + пирит $\rightarrow$ валлериит. Пирротин рудных серпентинитов характеризуется широкой вариацией состава, отвечает формулам: $\mathrm{Fe}_{6} \mathrm{~S}_{7}, \mathrm{Fe}_{8} \mathrm{~S}_{9}$, $\mathrm{Fe}_{9} \mathrm{~S}_{10}, \mathrm{Fe}_{11} \mathrm{~S}_{12}$ (табл.1). Вероятнее всего это связано с изменением количества серы в ходе его кристаллизации. Преобладают зерна с пониженным содержанием серы, что может говорить о довольно быстром уменьшении ее концентрации в рудном расплаве. Для всех зерен характерна примесь Ni (до 1 \%). 
Состав рудных минералов серпентинитов участка Хихку

\begin{tabular}{|c|c|c|c|c|c|c|c|}
\hline \multirow{2}{*}{$\begin{array}{c}\text { № } \\
\text { п/п }\end{array}$} & \multirow{2}{*}{ Минерал } & Формула минерала & \multicolumn{5}{|c|}{ Содержание компонентов, масс, $\%$} \\
\hline & (рассчитанная) & $\mathrm{S}$ & $\mathrm{Fe}$ & $\mathrm{Ni}$ & $\mathrm{Cu}$ & $\mathrm{Co}$ \\
\hline 1 & пирротин & $\left(\mathrm{Fe}_{5,96}, \mathrm{Ni}_{0,098}\right) \mathrm{S}_{7}$ & $\frac{39,88-39,90}{39,89}$ & $\frac{59,11-59,41}{59,12}$ & $\frac{0,90-1,02}{0,99}$ & - & - \\
\hline 2 & пирротин & $\left(\mathrm{Fe}_{11,53}, \mathrm{Ni}_{0,18}\right) \mathrm{S}_{12}$ & $\frac{36,04-38,27}{37,27}$ & $\frac{60,93-63,35}{62,24}$ & $\frac{0,28-0,94}{0,46}$ & - & - \\
\hline 4 & пирротин & $\left(\mathrm{Fe}_{7,93}, \mathrm{Ni}_{0,07}\right) \mathrm{S}_{9}$ & $\frac{39,22-39,46}{39,38}$ & $\frac{59,67-60,19}{59,93}$ & $\frac{0,59-0,75}{0,67}$ & - & - \\
\hline 5 & пирротин & $\left(\mathrm{Fe}_{8,87} \mathrm{Ni}_{0,1}, \mathrm{Pt}_{0,03}\right) \mathrm{S}_{10}$ & $\frac{38,51-38,71}{38,61}$ & $\frac{59,79-59,84}{59,81}$ & $\frac{0,72-0,9}{0,84}$ & - & - \\
\hline 6 & пентландит & $\left(\mathrm{Fe}_{3,98} \mathrm{Ni}_{4,75} \mathrm{Co}_{0,1}\right) \mathrm{S}_{8}$ & $\frac{33,52-33,60}{33,59}$ & $\frac{29,12-29,24}{29,15}$ & $\frac{32,67-36,52}{36,38}$ & - & $\frac{0,66-0,75}{0,73}$ \\
\hline 7 & халькопирит & $\mathrm{CuFe}_{1,1} \mathrm{~S}_{2}$ & $\frac{31,84-35,45}{34,95}$ & $\frac{30,22-31,40}{30,91}$ & $\frac{0,00-0,22}{0,20}$ & $\frac{32,83-32,89}{32,88}$ & - \\
\hline
\end{tabular}

Примечание: в числителе - минимальные и максимальные значения, в знаменателе - среднее.

Тальк-хлоритовые породы слагают вместе с роговообманковыми габбро-диоритами два интрузивных тела на участке Тундровый и интрузивное тело на участке Квинум.

Тальк-хлоритовые породы среднезернистые, характеризуются лепидобластовой структурой (широкое развитие листоватых минералов: хлорита и талька). Тальк-хлоритовые породы сложены преимущественно постмагматическими минералами (в \% от объема породы): тальк 30-40, хлорит 20-30, амфибол актинолит-тремолитового ряда 5-15, карбонат 5, серпентин $2-5$, роговая обманка $2-5$, рудные минералы до 10, среди акцессорных минералов наблюдаются удлиненно-призматические зерна апатита. Породы характеризуются присутствием реликтовой пойкилитовой структуры (хлоритизированная роговая обманка содержит в себе включения округлых зерен хадакристаллов оталькованного оливина и частично оталькованной уралитовой роговой обманки). Наблюдаются корродированные реликты роговой обманки, по которой интенсивно развивается амфибол актинолит-тремолитового ряда и хлорит с выделением мелкодисперсных зерен магнетита. Для амфибола актинолит-тремолитового ряда характерны сноповидные скопления вытянутых шнуроподобных зерен, огибающих изометричные выделения карбоната. Карбонат тесно связан с процессами серпентинизации и последующего оталькования хадакристаллов. В отличие от рудных серпентинитов, карбонат в тальк-хлоритовых породах присутствует в виде округлых зерен. Хлорит, в свою очередь, частично оталькован.

Таким образом, прослеживаются примерные (зерна оливина в породе не сохранились) последовательности замещения: пироксен $\rightarrow$ уралитовая роговая обманка $\rightarrow$ хлорит + магнетит $\rightarrow$ тальк + магнетит; роговая обманка $\rightarrow$ тремолит + хлорит + магнетит; оливин $\rightarrow$ серпентин + карбонат $\rightarrow$ тальк + карбонат.

Рудные минералы присутствуют в виде ксеноморфных зерен (пирротин, пентландит, халькопирит, пирит), распределенных в породе неравномерно и связанных с трещинками и зонами лимонитизации. Возможно, зоны лимонитизации образовались за счет выщелачивания и разрушения сульфидов. Пирротин, пентландит, халькопирит и пирит также наблюдаются в виде угловатых зерен, заполняющих пространство между листочками талька и хлорита (рис. 2В), что говорит о кристаллизации сульфидов уже после оталькования и хлоритизации. На участке Тундровый наблюдались в общей сульфидной массе единичные зерна сульфоарсенида никеля - герсдорфита, с формулой $\left(\mathrm{Ni}_{0.6}, \mathrm{Fe}_{0.2}, \mathrm{Co}_{0.3}\right)[\mathrm{AsS}]$.

\section{Габбро-диорить}

Габбро-диориты среднезернистые, равномернозернистые породы, характеризующиеся призматическизернистой структурой (за счет слагающих ее удлиненно-призматических зерен плагиоклаза и роговой обманки). Минеральный состав породы (в \% от объема породы): плагиоклаз - 50-60, роговая обманка - 30-50, рудный минерал - 5-10, карбонат 3-5.

Габбро-диориты участков Квинум и Тундровый характеризуются вкрапленной и прожилкововкрапленной минерализацией. Пирротин, как и в рудных серпентинитах участка Хихку, характеризуется широкой вариацией составов и преобладанием обедненных серой разностей. Химический состав его, соответствует формулам: $\mathrm{Fe}_{6} \mathrm{~S}_{7}, \mathrm{Fe}_{7} \mathrm{~S}_{8}, \mathrm{Fe}_{8} \mathrm{~S}_{9}, \mathrm{Fe}_{9} \mathrm{~S}_{10}$, $\mathrm{Fe}_{11} \mathrm{~S}_{12}$ с содержанием никеля (3,5-5,5 \%) (табл. 2).

Характерно присутствие никельсодержащих пирита, пирротина, а также - герсдорфита.

В породах широко развиты вторичные минералы. По роговой обманке развивается хлорит и волокнистый амфибол актинолит-тремолитового ряда, образуя многочисленные сноповидные скопления. Темноцветные минералы псевдоморфно замещены сульфидами и карбонатом, которые прорастают друг друга, образуя графические срастания (рис. $2 \Gamma$ ). Зерна цветных минералов корродированы. По плагиоклазам развивается каолинит. 
Таблица 2

Состав рудных минералов габбро-диоритов и тальк-хлоритовых пород участков Квинум и Тундровыци

\begin{tabular}{|c|c|c|c|c|c|c|c|}
\hline \multirow{2}{*}{$\begin{array}{l}\text { № } \\
\text { П/П }\end{array}$} & \multirow{2}{*}{ Минерал } & \multirow{2}{*}{$\begin{array}{c}\text { Формула минерала } \\
\text { (рассчитанная) }\end{array}$} & \multicolumn{5}{|c|}{ Содержание компонентов, масс,\% } \\
\hline & & & $\mathrm{S}$ & $\mathrm{Fe}$ & $\mathrm{Ni}$ & $\mathrm{Cu}$ & Co \\
\hline 1 & $\begin{array}{l}\text { никельсод. } \\
\text { пирротин }\end{array}$ & $\left(\mathrm{Fe}_{8,18}, \mathrm{Ni}_{0,77}\right) \mathrm{S}_{10}$ & $\frac{38,19-40,60}{39,93}$ & $\frac{54,06-58,34}{56,21}$ & $\frac{3,42-5,76}{4,95}$ & - & - \\
\hline 2 & пирротин & $\left(\mathrm{Fe}_{5,6}, \mathrm{Ni}_{0,4}, \mathrm{Pt}_{0,03}\right) \mathrm{S}_{7}$ & $\frac{39,76-40,33}{40,17}$ & $\frac{54,95-55,55}{55,00}$ & $\frac{3,77-3,82}{3,80}$ & & \\
\hline 3 & пирротин & $\left(\mathrm{Fe}_{10,5}, \mathrm{Ni}_{0,44}\right) \mathrm{S}_{12}$ & $\frac{37,44-38,54}{37,95}$ & $\frac{58,88-59,84}{59,14}$ & $\frac{2,24-2,58}{2,36}$ & - & - \\
\hline 4 & пирротин & $\left(\mathrm{Fe}_{7,7}, \mathrm{Ni}_{0,3}\right) \mathrm{S}_{9}$ & $\frac{39,12-39,46}{39,15}$ & $\frac{58,46-58,68}{58,53}$ & $\frac{2,42-2,50}{2,47}$ & - & - \\
\hline 5 & пирротин & $\left(\mathrm{Fe}_{8,7}, \mathrm{Ni}_{0,3}\right) \mathrm{S}_{10}$ & $\frac{38,71-38,88}{38,79}$ & $\frac{59,15-59,84}{59,31}$ & $\frac{1,87-1,98}{1,94}$ & - & - \\
\hline 6 & пентландит & $\left(\mathrm{Fe}_{3,6} \mathrm{Ni}_{4} \mathrm{Co}_{0,1}\right) \mathrm{S}_{8}$ & $\frac{33,60-36,51}{34,89}$ & $\frac{28,44-29,12}{28,70}$ & $\frac{33,41-36,88}{35,60}$ & - & $\frac{0,75-1,03}{0,89}$ \\
\hline 7 & халькопирит & $\mathrm{CuFe}_{1,1} \mathrm{~S}_{2}$ & $\frac{33,42-43,36}{36,17}$ & $\frac{30,79-32,52}{31,85}$ & ( & $\frac{25,85-34,18}{31,55}$ & (5) \\
\hline 8 & пирит & $\left(\mathrm{Fe}_{1,1}, \mathrm{Ni}_{0,01}\right) \mathrm{S}_{2}$ & $\frac{48,00-50,47}{48,15}$ & $\frac{48,40-48,60}{48,53}$ & $\frac{0,61-0,64}{0,62}$ & - & - \\
\hline & & & $\mathrm{S}$ & $\mathrm{Fe}$ & $\mathrm{Ni}$ & $\underline{\mathrm{As}}$ & Co \\
\hline 9 & герсдорфит & $\begin{array}{c}\left(\mathrm{Ni}_{0,6}, \mathrm{Fe}_{0,2}, \mathrm{Co}_{0,3}\right)[\mathrm{AsS} \\
]\end{array}$ & $\frac{16,14-18,22}{16,62}$ & $\frac{4,94-7,34}{6,25}$ & $\frac{18,97-27,32}{25,36}$ & $\frac{44,8-47,40}{46,48}$ & $\frac{3,07-10,67}{5,1}$ \\
\hline
\end{tabular}

Примечание: в числителе - минимальные и максимальные значения, в знаменателе - среднее.

Обсуждение результатов

Карбонат, как правило, брейнерит, в рудных сер- пентинитах образуется при реакциях серпентинизации оливина (I) и ромбического пироксена (II) $[5,6]$ :

$$
\begin{aligned}
& 2(\mathrm{Mg}, \mathrm{Fe})_{2} \mathrm{SiO}_{4}+2 \mathrm{H}_{2} \mathrm{O}+\mathrm{CO}_{2} \rightarrow(\mathrm{Mg}, \mathrm{Fe})_{3}\left[\mathrm{Si}_{2} \mathrm{O}_{5}\right][\mathrm{OH}]_{4}+(\mathrm{Mg}, \mathrm{Fe}) \mathrm{CO}_{3} \\
& \text { оливин серпентин брейнерит } \\
& 2(\mathrm{Mg}, \mathrm{Fe})_{2}\left[\mathrm{Si}_{2} \mathrm{O}_{6}\right]+2 \mathrm{H}_{2} \mathrm{O}+\mathrm{CO}_{2} \rightarrow(\mathrm{Mg}, \mathrm{Fe})_{3}\left[\mathrm{Si}_{2} \mathrm{O}_{5}\right][\mathrm{OH}]_{4}+(\mathrm{Mg}, \mathrm{Fe}) \mathrm{CO}_{3}+2 \mathrm{SiO}_{2} \\
& \text { ромбический пироксен } \\
& \text { серпентин } \\
& \text { брейнерит }
\end{aligned}
$$

Расчётное стехиометрическим путём отношение образующегося в ходе реакции серпентина к карбонату составит $\frac{V_{c}}{V_{\kappa}}=\frac{129,6}{32,26} \approx \frac{4}{1}$.

Из расчётов видно, что в ходе реакции серпентинизации оливина объёмное количество образовавшегося карбоната должно быть меньше количества серпентина примерно в 4 раза.

Реально в серпентинитах участка Хихку количество карбоната меньше серпентина примерно в 4,4 раза. Следовательно, карбонат в породе является продуктом автометасоматической серпентинизации оливина и пироксена, а не продуктом наложенных метасоматических преобразований. Об этом свидетельствует и симплектитовая структура прорастания карбоната рудным минералом, которая указывает на серпентинизацию зерен оливина и пироксена одновременно с кристаллизацией рудной фазы. Это не противоречит диапазону температур серпентинизации и кристаллизации пирротина, так как серпентинизация происходит при температурах не выше $400^{\circ} \mathrm{C}$ [6], пирротин кристаллизуется в температурном интервале $370-410^{\circ} \mathrm{C}$ [7], а по палеотермометрическим определениям $400-600^{\circ} \mathrm{C}$ [8]. По данным некоторых исследований [9], высокое содержание флюидов в суль- фидной жидкости может понижать температуру кристаллизации рудных минералов, что определяется высокой ролью флюидов в формировании пород габбро-кортландитового комплекса Камчатки.

Сравнение вторичных изменений исследуемых пород с норильским типом показало следующее.

В норильском типе интрузий, контролирующих оруденение, доля вторичных преобразований базитовых пород в некоторых случаях достигает 15\% объема породы, ультрабазитовых пород 10\% [10], в отличие от изучаемых пород, где наблюдается полная переработка первичных ультрабазитовых и частичная базитовых (до 40-45\% объема породы) пород вторичными минералами.

Для ультрабазитов норильского типа характерны массивные и равномерно-вкрапленные руды, а для базитов вкрапленные и прожилково-вкрапленные руды. В исследуемых породах ультрабазиты характеризуются равномерно-вкрапленными сульфидными рудами, базитовые породы вкрапленными и прожилково-вкрапленными.

Базиты и гипербазиты норильского типа отличаются большим разнообразием пород, связанных с сульфидной минерализацией: габбро-долериты, габбро-нориты, лейкогаббро и их взаимными переходами, 
соответственно и большим разнообразием структурных признаков: офитовая, пойкилоофитовая, пойкилитовая, призматически-зернистая структуры [11]. Породы дукукского комплекса участков Хихку, Квинум и Тундровый характеризуются преимущественно реликтовыми пойкилитовыми и призматическизернистыми структурами.

Вкрапленные и прожилково-вкрапленные сульфидные руды в породах норильского типа характеризуются преимущественно каплевидной формой, что, по мнению некоторых исследователей, говорит в пользу ликвационной теории происхождения руд [11], реже наблюдаются в интерстициях оливина, клинопироксена и плагиоклаза. В исследуемых породах вкрапленные руды наблюдаются в рудных прожилках, в интерстициях вторичных минералов, в их трещинках, огибая каждый листочек вторичного минерала и заключая в себе отдельные листочки и волокна.

В базитах норильского типа темноцветные минералы замещаются преимущественно хлоритом [11]. Для базитов исследуемых пород характерно замещение первичных темноцветных минералов как хлоритом, так и сульфидами, и карбонатом, взаимным их срастанием. Эти особенности отмечаются Е. К. Козловым в Мончегорских медно-никелевых месторож- дениях, который относит их к позднемагматическим [12].

Для равномерно-вкрапленных и массивных руд как норильского типа, так и исследуемых пород, характерна сидеронитовая структура [13]. В отличие от пород норильского типа, в рудной массе серпентинитов исследуемых пород наблюдаются графические срастания пирротина с карбонатом, единичные волокна и сростки волокон серпентина.

Все перечисленные отличия объясняются разной геодинамической природой сравниваемых объектов. Если для норильского типа характерна внутриплитная обстановка под влиянием плюма, определяющего более «сухой» родоначальный расплав, толеитовый тренд (рис. 3) [14, 15] его эволюции и относительно «спокойные» условия ликвации в условиях растяжения, то для шанучского - определяющим фактором была субдукционная обстановка и, как следствие, более гидратированные исходные расплавы с известково-щелочным трендом эволюции (кортландиты) [15] в условиях сжатия и более существенная тектонизация промежуточных очагов, что привело к «растаскиванию» рудных тел от их первоначального залегания с образованием собственно интрузивных тел существенно сульфидного состава (Шануч).
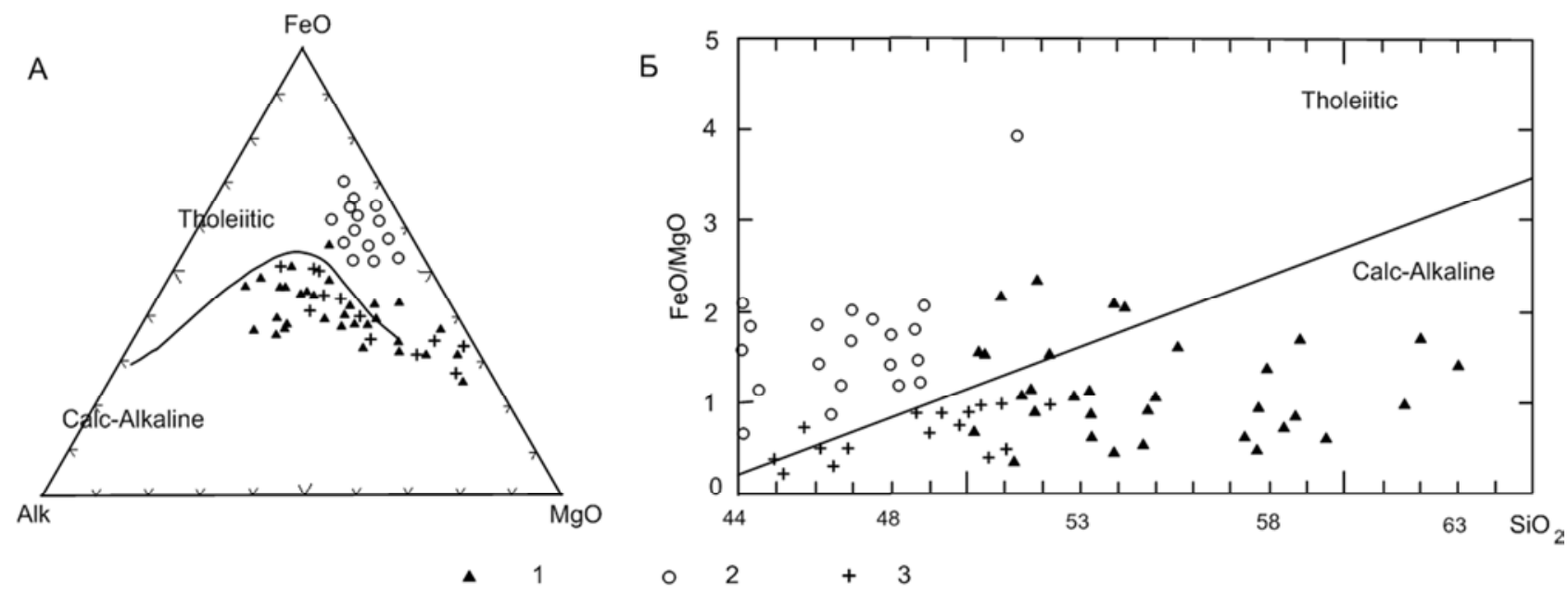

Puc. 3. Составы никеленосных базитов на классификационных диаграммах. А - по [14]; Б - по [15]. Условные обозначения: 1 - базиты Шануча [16], 2 - базиты Талнахской интрузии [13]; 3 - базиты массива Кувалорог [17].

\section{Выводы}

В рудных телах Дукукского комплекса на участках Хихку, Квинум и Тундровый, было установлено два типа руд - равномерно-вкрапленные руды, характеризующиеся сидеронитовой структурой в серпентинитах, а также вкрапленные и прожилково-вкрапленные руды тальк-хлоритовых пород и габбро-диоритов участков Квинум и Тундровый.

Стехиометрическим путем рассчитано отношение объемов карбоната и серпентина, которое свидетельствует об их автометаморфической природе, а не матасоматической. Карбонат образовался во время увеличения объёма массива, за счет серпентинизации, в автометаморфическую стадию, а его графическое срастание с сульфидами указывает на внедрение рудного вещества при отжиме его из нижних этажей. Помимо этого, породы, слагающие массивы, отличаются широким развитием других автометаморфических изменений первичных минералов, подтверждающих наши предположения, в том числе замещением сульфидами пироксена и амфибола, многочисленными скоплениями разобщенных волокон серпентина в рудной массе и выделением рудного минерала в интерстициях вторичных минералов.

Вторичные изменения минерального состава базитов и ультрабазитов в интрузиях дукукского комплекса отличаются от подобных пород в месторождениях Норильского типа. Они указывают на существенный 
вклад в рудный процесс эпигенетических изменений, что согласуется с представлениями о более высокой гидратированности исходных расплавов. Графические срастания карбоната с пирротином, многочисленные единичные волокна серпентина в рудной массе и ряд других признаков позволяют сделать вывод о том, что вторичные изменения имели место до окончательной кристаллизации массивов в позднемагматическую стадию.

\section{ЛИТЕРАТУРА}

1. Еременко, A. В. К модели $\mathrm{Cu}-\mathrm{Ni}$ рудообразования при формировании ультрамафитовых массивов южной части Камчатского полуострова / А. В. Еременко, Д. В. Еременко, В. А. Жабин // Вестн. Воронеж. госуд. ун-та. Сер. Геология. 2014. - № 1. - C. 73-78.

2. Полетаев, B. А. Камчатская платиноидно - никеленосная зона - геология и рудоносность/ В. А. Полетаев: автореф. дисс. ... к-та геол.-мин. наук 05.06.01. - М., 2004. - 55 с.

3. Соловьев, А. В. Изучение тектонических процессов в областях конвергенции литосферных плит методами трекового датирования и структурного анализа/ А. В. Соловьев: автореф. дисс. ... к-та геол.-мин. наук 05.06.01. - М., 2005. - 59 с. 4. Исаенко, М. П. Лабораторные методы исследования руд : учеб. для вузов / М. П. Исаенко, Е. Л. Афанасьева. - Москва : Недра, 1992. - 254 с.

5. Бетехтин, А. Г. Курс минералогии: учебное пособие / А. Г. Бетехтин ; под науч. ред. Б. И. Пирогова и Б. Б. Шкурского. - Москва : КДУ, 2008. - 736 с.

6. Печерин, В. Н. Минералого-петрографическое исследование серпентинитов и серпентинизацииультрабазитов Полярного Урала : материалы Х Междунар. молодежной науч. конф. Севергеоэкотех / В. Н. Печерин. - Ухта : ГТУ, 2009. C. 299.

7. Светлицкая, Т. В. Определение температур образования сульфидов массивных руд Чайского $\mathrm{Cu}-\mathrm{Ni}$ месторождения
(Северное Прибайкалье) / Т. В. Светлицкая, Е. В. Кислов // Ультрабазит-базитовые комплексы складчатых областей и связанные с ними месторождения: материалы III Междунар. конф. - Екатеринбург : Ин-т геологии и геохимии УрО PAH, 2009. - T. 2. - С. 186-189.

8. Горбунов, Г. И. Геология и генезис сульфидных медноникелевых месторождений Печенги / Г. И. Горбунов. Москва : Недра, 1968. - 230 с.

9. Конников, Э. Г.Состав флюидных включений в интрузивных породах норит-кортландитового комплекса Камчатки / Э. Г. Конников, О. Н. Васюкова // Геология рудных месторождений. - 2007. - Т. 49. - № 3. - С. 256-267.

10. Додин, Д. А. Платинометальные месторождения России : монография / Д. А. Додин, Н. М. Чернышов, Б. А. Яцкевич. - Санкт-Петербург : Наука, 2000. - 755 с.

11. Рябов, В. В. Магматические образования Норильского района. Т. 1. Петрология траппов / В. В. Рябов, А. Я. Шевко, М. П. Гора. - Новосибирск : Изд-во Нонпарель, 2001. - 408 с.

12. Козлов, E. К. Естественные ряды горных пород в дифференцированных никеленосных интрузиях Центральной части Кольского полуострова и их металлогения: автореф. д-ра геол.- минерал. наук / Е. К. Козлов. - Ленингр. ун-т. - Ленинград, 1972. $-70 \mathrm{c}$.

13. Золотухин, В. В. Петрология Талнахской рудоносной дифференцированной трапповой интрузии: труды института геологии и геофизики АНСССР / В. В. Золотухин ; под науч. ред. акад. Соболева В. С. - Вып. 186.- Новосибирск, 1975. -435 c.

14. Селянгин, О. Б. Новые данные о строении и эволюции никеленосного интрузива Кувалорог, Южная Камчатка / О. Б. Селянгин // Науч.-исслед. геотехнол. центр ДВО РАН. Вестник Краунц. Науки о Земле. 2007. - №1. - Вып. - № 9. C.111-126.

15. Степанов, В. А. О возрасте Шанучского медно-никелевого месторождения / В. А. Степанов, Ю. П. Трухин ; представлено акад. В. Г. Моисеенко // Доклады Академии наук. - 2007. - Т. 417. - № 1.- С. 84-86.

\section{ФГБОУ ВО «Воронежский государственный университет»}

Еременко Дарья Вадимовна преподаватель кафедры общей геологии и геодинамики

E-mail: Krilova_dasha@mail.ru

Тел.: +7 (473) 2208926

Еременко Александр Викторович, кандидат геологоминералогических наук, дочент кафедры общей геологии и геодинамики

E-mail: averema@yandex.ru

Тел.: +7 (473) 2208926

Золотарева Галина Сергеевна, кандидат геологоминералогических наук, дочент кафедры общей геологии и геодинамики

E-mail: akcessoriy@mail.ru; Тел.: +7 (473) 2208926

\section{Voronezh State University}

Eremenko D. V., Teacher of the General Geology and Geodynamics Department

E-mail: Krilova_dasha@mail.ru

Tel.: +7 (473) 2208926

Eremenko A. V., Candidate of Geological and Mineralogical Sciences, Associate Professor of the Common Geology and Geodynamic Department

E-mail: averema@yandex.ru

Tel.: +7 (473) 2208926

Zolotareva G. S., Candidate of Geological and Mineralogical Sciences, Associate Professor of the Common Geology and Geodynamic Department

E-mail: akcessoriy@mail.ru; Tel.: +7 (473) 2208926 